\title{
FROM UNDIVIDED STATE POWER TO THE SYSTEM OF DECONCENTRATED AND DECENTRALISED STATE POWER. THE POLITICAL TRANSFORMATION OF POLAND
}

\author{
by Alfred Lutrzykowski
}

\section{INTRODUCTION}

This paper is not an attempt to present the process of political changes that occurred in Poland after the end of the Second World War. Its aim is to indicate and explain the characteristics of the process of political change which after 1945 turned Poland into a totalitarian socialist state, and from 1989 led to the construction of the democratic state.

The fate of Poland and other Eastern European countries was decided by the strategic interests of the great powers. The memory of the victims of war and democratic axiology gave way to the calculations and domination of force. Many nations were deprived of subjectivity and the possibility of sovereign choice in their future development. In Poland the place of the sovereign nation had been taken by a small group of politicians who became the plenipotentiaries of the Soviet leadership.

The creation of the totalitarian system was an essential precondition for the implementation of the Stalinist model of society entirely dominated by the Communist Party, the state described as socialist, and its apparatus of repression. The rule over the nation, although it was called the dictatorship of the proletariat, was a dictatorship over the enslaved society. Only 
the gradual erosion and finally the collapse of the centre of communist world, created in this part of Europe the possibility to choose freely the model of collective life. The victory of the Polish Solidarity and the fall of Berlin Wall alike symbolize the overcoming the post-Yalta order and the return of these nations to the European, democratic idea of social order. After 1989 the political solutions in which power is protecting the needs, interests and aspirations of each individual as well as the common good, considered the summum bonnum, were chosen. This power is by its very nature decentralised.

\section{POLAND AFTER YALTA AND THE END OF WAR IN EUROPE. SOCIALIST REVOLUTION WITHOUT THE PARTICIPATION OF THE MASSES}

After the end of World War II the process of construction of a new territorial and political order began in Europe. It was mainly the result of the series of decisions made by the great powers and the existing international balance of power. The strengthening of the position of the Soviet Union led to the significant growth of its influence on the situation. Assessing the course of events and the policies of Stalin, Winston Churchill in his speech given exactly 64 years ago (March 5, 1946) in Westminster College in American city of Fulton, Missouri, used the term "the iron curtain" which permanently entered the vocabulary of history of the postwar Europe. "The iron curtain" which descended - according to Churchill - from Stettin in the Baltic to Trieste in the Adriatic ${ }^{1}$ for years divided Europe into two hostile camps, isolating the countries lying east of Oder (or precisely Elbe) from the democratic Western Europe.

Poland found itself in the sphere of Soviet domination which brought far-reaching limitations on her sovereignty and the chances for demo-

1 From Stettin in the Baltic to Trieste in the Adriatic, an iron curtain has descended across the Continent. Behind that line lie all the capitals of the ancient states of Central and Eastern Europe. Source: Robert Rodos James, Winston S. Churchill: His Complete Speeches 1897-1963, Dom Wydawców Chelsea, New York and London, vol. VII, 1943-1949, pp. 7285-7293. 
graphic and cultural development for almost half a century. For Poland the loss of around 6 million people, the almost complete destruction of the infrastructure and significant changes of borders were the most important consequences of the war. The accession to power of the so called communist left, politically dependent on the Soviet leadership and using its (not only political) support, decided the nature of the political system and the antidemocratic nature of state power. The state apparatus became an instrument for the realisation of the political, social, economic and cultural ideas of the Polish Workers' Party (since December 1948 Polish United Workers' Party), completely subordinated to the leadership of the Communist Party of the Soviet Union. Also the rules and procedures for the creation of state organs, their structure, nature, functions and methods of working were closely modelled on the Soviet solutions.

One of the doctrinal fundaments of the political system was the principle of unity and indivisibility of power of the state created under the dictatorship of the proletariat. The propaganda and political tactics used almost until the end of the 1940s, were based on the language suggesting that: "the power in Poland's future must go into the hands of representatives of the broadest sections of the nation, representing the interests of the workers, peasants and intelligentsia." 2 It was to be the "people's democracy." The quoted document stressed that: "all authorities, from the democratic Provisional Government to local city and village, local-government will be nominated according to the will of the majority of the Polish nation: the workers, peasants and intelligentsia."3 However, these declarations were increasingly different from the political practice. The communist left, with the utmost determination, sought to gain the full power, breaking the principles of democracy, notably political pluralism and civil liberties.

The political situation was complicated because of the doctrinal disputes and conflict within the leadership of PWP/PUWP around the concept of the so called Polish way to socialism. The group of communists who

2 „O co walczymy. Deklaracja programowa Polskiej Partii Robotniczej” z listopada 1943 r., [in:] Wizja programowa Polski Ludowej. Dokumenty i materiaty 1942-1948, Warszawa 1979, p. 106.

3 Ibidem, s. 109. 
stressed the necessity to fully respect the Stalin's thesis of constant intensification of the class struggle in the process of construction of socialism and the need to take "a struggle for the revolutionary vigilance," emerged victorious from these debates. The developments in Poland remained closely connected to the tense international situation (the beginning of the Cold War) and the pressure of Communist Information Bureau (Cominform). ${ }^{4}$ The decisions of the $3{ }^{\text {rd }}$ Plenum of Central Committee of the PUWP in November 1949 initiated the purges of the cadres and the arrests of people suspected of the so called rightist-nationalist deviation. The victorious group led by B. Bierut dominated the party leadership leading to the arrest of W. Gomulka and his closest associates. The new leadership imitated the Soviet political system and mechanisms of apparatus of power, ignoring the specificities of Poland, its traditions and the achievements of its democratic institutions. The adaptation of these models was manifested even by the Polish version of the "personality cult."

At the same time the process of concentration of power of the narrow group of people began and deprived of their independence other political parties, the local power apparatus, companies, cooperatives, social organisations and local government. The act from March 20, 1950 on the local organs of unified state power (Dz.U. 1950 No. 14, poz. 1305) abolished the local government, regarded as a relic of the pre-war regime. The period of dismantling self-government structures of society and its various environments (medical, pharmaceutical self-management) began. The legal and artisan local government effectively resisted the liquidation and, as a consequence, it was subjected to serious organisational restrictions. The new network of executive organs based on the principle of extreme centralisation emerged. The term "self-management" was removed from the official vocabulary and even from the terminology of academic disciplines. The same happened to the concept of "public authority," identified with the tasks associated with the organisation of collective life,

\footnotetext{
${ }^{4}$ In June 1948 the Information Bureau passed the resolution on collectivisation in the states of people's democracy which caused the considerable reservations of the Polish delegation as from September 1944 Poland had been implementing the land reform aiming at giving the land to the peasants.

5 Journal of Laws of the Republic of Poland No. 14 of 20 March 1950, item 130.
} 
directing it, satisfying the various social needs and securing the interests of citizens. From now on only the concept of "state power" was used (later the not fully logical term "organs of state power and administration" appeared). "State power" was unified and undivided. The leadership of the "people's" state did not intend to give any concessions to anyone in the sphere of power.

As a result of the intensification of propaganda, campaigns inspired by the party leadership, the atmosphere of suspicion and intolerance deepened and the methods used by the government became more repressive. The security apparatus received an order to intensify the struggle against subversion, sabotage, foreign intelligence, wrecking etc. Between 1951 and 1954, 19 political opponents (officers, party and state officials) were sentenced to death and executed. In this way the totalitarian nature of the system of power created and led - under the careful supervision of the Soviet representatives - by B. Bierut, H. Minc, J. Berman, F. Jóźwiak and R. Zambrowski - deepened. The state apparatus, fully controlled by the party leadership, had an absolute monopoly on the use of governmental authority. This style of governance was called the democratic centralism. The slogans about the worker-peasant alliance, the national front or the construction of a strong, socialist, independent Poland as a country of equality and social justice proclaimed at the same time were simply propaganda and an instrument of indoctrination.

\section{THE THAW WHICH DID NOT BRING SPRING}

The changes in the Soviet Union after the death of Józef Stalin (March 5,1953 ) and the end of war in Korea (July 1953) and Indochina (July 1954) reduced tensions in international relations. The arrest, sentence to death and execution of L. Beria (June 1953) confirmed also that the red revolution "devours its own children." In Poland timid attempts to eliminate the violations of basic civil rights and civilised rules of functioning of the state were made in the spring of 1954. At the end of 1954 the Ministry of Public Security was dissolved, several important officials brought to justice and the leadership of the new security administration was changed. How- 
ever, these moves did not fulfil the expectations of society. An atmosphere of criticism of authorities was emerging. However, it lacked the organised forms of expression of opinions and demands. The monopoly on information belonged to the party. The social organisations and trade unions, deprived of independence, acted as the "transmission of party to the masses." The so called allied parties (United Peasant Party and Democratic Party) were entirely dominated by PUWP.

The $20^{\text {th }}$ Congress of CPSU (14-25 February 1956) provoked the outburst of criticism against the system of government and condemnation of methods used by the apparatus of power, especially the crimes that it committed. In Poland the Khrushchev's secret speech made a startling impression even in the circles of party activists. However, the de-Stalinisation had not taken the expected speed and scale. The deteriorating economic situation significantly affected public opinion. At the end of June 1956 the first large-scale workers' protest took place in Poznań. 55 people lost their lives during the protest and further 19 died due to injuries ( 66 of them were civilians 6 ). The threat of "cutting off the hand" raised against the authorities formulated by the Prime Minister J. Cyrankiewicz was more than just a rhetorical device. These events caused public shock and the criticism from the West. E. Ochab, the General Secretary of the PUWP Central Committee claimed that the Poznan events were the effect of planned action of imperialist circles and counterrevolutionary underground. However, the disagreements on assessments of the June conflict, existing policy and program of further actions emerged within the party leadership. W. Gomułka, released during the Eighth Plenum of the Central Committee of the Polish United Workers' Party (20-21 October 1956), declared: "The unsuccessful attempt to present the painful tragedy of Poznań as a work of imperialist provocateurs was a great political naivety," and added: "The causes of the tragedy of Poznan and discontent of the

\footnotetext{
6 Sprawozdanie z prac Komisji KC PZPR powołanej dla wyjaśnienia przyczyn i przebiegu konfliktów społecznych w dziejach Polski Ludowej, "Nowe Drogi”, Special issue, Warszawa 1983, p. 29.
} 
working class lay within the leadership of the party and the government it accumulated over the years."

However, the next years did not bring significant political changes such as democratisation or faster economic development which would raise the standards of living. The deterioration of relations with the Catholic Church, the anti-Semitic campaign and the events of March 1968 were the manifestations of the deepening conflict within the political establishment and the disaccord between authorities and society. W. Gomułka's authority was exhausted and he was not able to face the escalating conflict. Its outburst occurred in Danzig (Gdańsk) after the decision to increase food prices was proclaimed on December 12, 1970. The unrest spread to other cities of the Polish coast. 44 people died during these events. ${ }^{8}$

Again, the turn in party's policy was proclaimed. Changes in the party and state leadership occurred. E. Gierek became the leader of the party and P. Jaroszewicz the Prime Minister. The political group formed in these conditions ruled the party and the state for the following decade. The economic recovery achieved by the investment of funds obtained from the Western loans brought a rise in wages and an improvement in living standards. However, due to many mistakes, the economy began to sink into crisis. The so called economic manoeuvre did not help. The indebtedness increased to dangerous level. Trying to prevent the collapse of economic balance the authorities decided to raise the prices. At the end of June 1976 unrest, strikes and demonstrations occurred in many Polish cities. The events in Radom and Ursus reverberated most loudly. The humiliated Prime Minister declared on television that the government proposal for an increase food prices was withdrawn.

It was the second case, after December 1970, of authorities capitulating under the strong pressure from the masses. Such belief certainly was an important prerequisite for the activation of the hitherto illegal opposition groups which in September 1976 created the Workers' Defence Committee, an informal body whose activity became increasingly known, especially

\footnotetext{
7 Wystąpienie W. Gomułki na VIII Plenum KC PZPR, October 20, 1956, "Nowe Drogi”, Warszawa 1956, No. 10, p. 28.

8 Sprawozdanie z prac Komisji ..., op. cit., p. 44.
} 
among the workers. In 1978 the Initiating Committee of the Free Trade Unions and Young Poland Movement were formed. The Confederation of Independent Poland was created on September 1, 1979. The election of Cardinal Karol Wojtyła as a new pope in October 1978 and his visit to Poland in June 1979 had a great impact on social atmosphere. They were signs of approaching socio-political crisis.

\section{THE PENULTIMATE ACT OF LONG AGONY OF "REAL SOCIALISM"}

In mid-1980 the strikes began in Poland. The epicentre of events was located in Danzig (Gdańsk) in the shipyard named after creator of the Bolshevik Russia - V. Lenin. The workers' protests intensified reaching the scale unprecedented in the post-war Polish history. The authorities were unable to control the crisis and lost control and initiative in face of determination of the strikers and support they received. The spontaneous protest transformed into an organised movement. The decisive part was played by the Inter-Enterprise Strike Committee led by Lech Wałęsa. On the $30^{\text {th }}$ August the party leadership received the reports of special government commissions negotiating with the strikers. The next day, on August 31,1980 , the agreements on fulfilment of workers' demands were signed in Danzig (Gdańsk). The undivided power was severely compromised: the party and the state authorities accepted the pluralism of trade unions, right to strike, freedom of speech and publication and access to the mass media. ${ }^{9}$

Facing the threat of loss of power the conservative forces counterattacked. The party tried to regain the initiative by announcing a "socialist renewal." However, the freed social energy and the first institutionalised, organised forces demanding profound social, political and economic changes and could not be effectively contained. The changes within the party leadership and state apparatus and the program of the Ninth Extraor-

\footnotetext{
9 Protokoły porozumień Gdańsk Szczecin Jastrzębie. Statut NSZZ „Solidarność”, Krajowa Agencja Wydawnicza, Warszawa 1980, p. 2 et seq. [Documents].
} 
dinary PUWP Congress did not help. Even the martial law declared on the December 13, 1981 by the State Council could not prevent the struggle for the real renewal of, in the words of speech given by John Paul II in June 1979, "the image of this land."

The society experienced a psychological shock. Over five thousand opposition activists were arrested. During the pacification of "Wujek" mine in Katowice nine miners lost their lives. The military regime was imposed on many workplaces and state and economy administration. The suspension of trade union activity, the limitation on the freedom of movement, stricter censorship, monitoring of phone calls and post, and active prosecution of cases of breaking the martial law by the military courts are only some examples of the limitations of civil rights. The authorities considered the declaration of martial law a necessity. The decree of the State Council declared that its aim was: "to ensure the safety of basic interests of state and its citizens in order to create the conditions necessary for the defence of sovereignty and independence of People's Republic of Poland as well as peace and public order" (Dz. U. 1981 No. 29 , poz. $\left.155^{10}\right)$.

The new non-constitutional body, the Military Council of National Salvation (WRON), appeared on the political scene. Its creation was justified by the threat of outbreak of civil war and the fact that "The explicit preparations for a reactionary coup d'etat and the threat of terror might result in bloodshed".11 In its proclamation WRON declared that its creation "does not affect the power of or remove the responsibility from any institution." Its leader general W. Jaruzelski explained that the formation on the Council was a necessity caused by the crisis in which the actions of the parliament, the government and the state administration did not produce the expected results. Polish society and the world were assured that the Council was a provisional institution aiming at paving the way for the state to act in a normalised socio-political and economic situation. The last sentence of the quoted document stated that it was the last chance

\footnotetext{
10 Journal of Laws of the Republic of Poland No. 29 of 1981, item 155.

11 Proklamacja Wojskowej Rady Ocalenia Narodowego, [in:] Stan wojenny w Polsce. Refleksje prawno-polityczne. Praca zbiorowa, ed. F. Prusak, Książka i Wiedza, Warszawa 1982, p. 189.
} 
for the Polish nation "to restore the order by its own effort"12 suggesting the threat of foreign (Soviet or Warsaw Pact) invasion.

The atmosphere in Poland was the one of sadness and disbelief in the possibility of changes leading to an improvement in living conditions or a restoration of basic democratic freedoms. However, over time it became clear that the mechanism of the martial law, its supporters and leaders were not able to completely subjugate the society and deprive it of either the will to resist and or the hope for change. The trade union movement revived in secrecy. Although the authorities arrested the Solidarity's leaders they did not manage to destroy its secret structures which gradually regained the initiative. The activists who lost their jobs and were forced to agree not to engage in trade unions' activity joined the underground structures of the Union. The leadership and hierarchy of the Catholic Church clearly favoured the revival of Solidarity.

The economic reform, in the eyes of the party and the government considered the obligation towards the society under harsh martial law, did not bring the expected results. Even the party vanguard could no longer be mobilised for the consistent and effective agitation and organisational activity. Also the party's and authorities' ties with the industrial working class, represented as a bastion of communist ideology, were only wishful declarations. The intensifying economic crisis became the invisible enemy of the system causing the apathy and discouragement and finally explicit impatience in the Polish society. The attempts to reform the economic system were nothing more than superficial corrections. The limit of changes was set by the principle of central planning and the doctrine of "unified state power." The authorities' attempts to limit the results of for example the supply crisis did not eliminate the discontent of society.

\footnotetext{
12 Ibidem, p. 193.
} 


\section{THE GENERAL'S POLITICAL GAMBIT AND THE EPILOGUE OF REAL SOCIALISM}

The divergence of opinions on the situation in Poland and solutions to her fundamental political and economic problems became visible within the party and the state apparatus. On the August 31, 1988 the Minister of Internal Affairs Czesław Kiszczak met Lech Wałęsa. The representative of the Catholic Church and the Secretary of PUWP Central Committee were also present at the meeting. It was the breakthrough which meant the authorities' resignation from the use of force and abandonment of secret preparations to declare the state of emergency. In mid-September another meeting with the representatives of the United Peasant Party, the Democratic Party, the trade unions (including the still illegal Solidarity) and the Church took place. During the meeting the conflict over legalisation of Solidarity emerged. Some spoke of convening the Round Table. The $10^{\text {th }}$ PUWP Central Committee Plenum revealed the strong disagreement on the attitude to Solidarity within the party leadership. However, the removal of six of the Politburo members was not a breakthrough and a significant proportion of the party members still strongly resisted change. Only in January did the party leadership and general Jaruzelski pass a resolution on political and trade union pluralism. On January 29 the meeting of Lech Wałęsa and general Cz. Kiszczak began the organisational preparations for the Round Table.

The talks began on the $6^{\text {th }}$ February and lasted until the $5^{\text {th }}$ April. They were held by three groups, one focusing on economy and social policy, one on trade union pluralism and one on political reforms. The final Round Table Agreement brought many important decisions which opened the way for the more profound changes. Already during the negotiations the Round Table was criticised by part of the opposition which accused the participating Solidarity activists of treason and lack of legitimacy. However, the events occurred rapidly one after another. On the $7^{\text {th }}$ April the Parliament introduced changes to the constitution introducing the legislation on Senate, President (who replaced the State Council) and the electoral laws to the Parliament and Senate. The Parliament adopted both electoral laws, an amendment to the legislation on trade unions and the 
Law on Associations (Dz. U. z 1989 r. Nr 19, poz. 101-105'3). Soon the State Council proclaimed that the elections would be held on the $4^{\text {th }}$ and the $18^{\text {th }}$ June, 1989. The independent Self-Governing Trade Union Solidarity and the Independent Self-Governing Trade Union of Individual Farmers Solidarity were legalised. The publication of "Tygodnik Solidarność" was resumed and at the beginning of May the first issue of an independent journal "Gazeta Wyborcza" appeared.

The elections to Parliament were not completely free (opposition groups received only 35 percent of seats) but ended in Solidarity's success. The opposition's candidates got 99 out of 100 seats in Senate. The difficult process of forming the government began. The slogan "Your president, our Prime Minister" appeared. After General W. Jaruzelski was elected to the office of President of Poland the government was formed by the opposition representative, Tadeusz Mazowiecki. On the December 29, the Parliament (called the Contract Parliament) introduced a fundamental change to Constitution (Dz. U. 1989 No. 75, poz. 44414). It restored the traditional, historical name of "Republic of Poland" which was proclaimed "the democratic state ruled by law, implementing the principles of social justice" (Article 1). The Constitution also declared that "in the Republic of Poland the supreme power belongs to the People" (Article 2.1). These were more than the superficial changes as before the Constitution stated: "People's Republic of Poland is a socialist state" and "the power belongs to the workers of towns and villages" (Article 1 before revision). Another important decision was the declaration of political pluralism, economic freedom, protection of property, right of inheritance and "total protection of personal property" (Article 7).

The Constitution promised the restoration of local government and other forms of self-management (Article 5). Even before these declarations the Parliament passed the Medical Act on the May 17, 1989 (Dz. U. 1989 No. 30, poz.158 ${ }^{15}$ ) and the law on local governmetn of several professions on the 30 May 1989 (Dz. U. 1989 No. 35, poz. 194'16). On the March 8,

\footnotetext{
13 Journal of Laws of the Republic of Poland No. 19 of 1989, items 101-105.

14 Journal of Laws of the Republic of Poland No. 75 of 1989, item 444.

15 Journal of Laws of the Republic of Poland No. 30 of 17 May 1989, item 158.

16 Journal of Laws of the Republic of Poland No. 35 of 30 May 1989, item 194.
} 
three laws on local government were adopted. The law revising the Constitution included the statements important for the emerging system of power: "Local government is a basic form of organisation of the public life of the community" (Article 43.1) and "The community is a legal person and performs public tasks on its own behalf within the principles laid by the law" (Article 44.1). Such solutions meant the end of the "unified and undivided" state power. Local government became part of public administration at the community level.

These and other changes in the mechanisms and principles of the organisation of public life caused the increasing deconcentration and decentralisation of power. In this way Poland made the historical political changes which led to the creation of a system based on democratic values and respecting the political standards of civilised societies: freedom and pluralism, the division of power, the right of local communities' right to local government and the principle of subsidiarity which strengthens the citizens and theirs communities.

The most serious resistance to the system emerged in Poland. The process of gradual destruction of mechanisms of power became clearly visible in the late 1970s. The events of August 1980 were an expression of consolidation of the resistance forces and their ability to take an organised action. They were also the result of the crisis of program of construction of socialism in Poland. The social acceptance of the party's program of "renewal of socialism" and subsequent "fundamental" reforms and changes reached the critical level and threatened the outburst of public discontent. The authorities' inability accurately to assess the amount of social energy and basic factors contributing to economic progress (labour force, raw materials, capital, science and technology) grew out of the model characteristics of socialist economy (centralisation, unreal concept of social ownership, marginalisation of private initiative). ${ }^{17}$ The dogma of the

17 See: M. Bałtowski, Gospodarka socjalistyczna w Polsce. Geneza-rozwój-upadek, PWN, Warszawa 2009, p. 309 et seq.; W. Roszkowski, Gospodarka. Wzrost $i$ upadek systemu nakazowo-rozdzielczego, PWN, Warszawa 2008, passim 
superiority of a socialist economy over the capitalist economy did not allow for the search of modernising solutions used in other economic systems.

For Poland, Europe and the world the year 1989 was the turning point in the post-war history, closing the era of post-Yalta political and territorial order and opening the period of profound changes in the countries of the Eastern Block. The changes which occurred after the Round Table agreements and elections in June 1989 opened up the possibility for fundamental transformation of the nature of public authority and economic system. The erosion of the Soviet Union accelerated the collapse of the ability of authorities in the other socialist states to control political and social life. Also there the political establishment disintegrated and the decision-making centres revealed the variety of doctrinal and political orientations. The authority and position of the communist party quickly collapsed. In January 1991 PUWP finally disappeared from the political scene now occupied by the new forces calling for the radical reconstruction of social order and political system. The attitude of the majority of society and support for the projects of these changes shaped the new alignment of political forces in the countries of "real socialism."

The disintegration and collapse of the Soviet Union and its sphere of domination meant that the period of formation of new political, and soon also territorial, order began in the history of Europe. The Cold War was ending just like the era of "real socialism" in Central and Eastern Europe. Poland largely contributed to this process, showing the faith in the final victory of the idea of free, democratic society and the possibility of creating the state which protects its interests and independence among the increasingly integrated modern European nations.

The last twenty years have not eradicated the traces of real socialism or fulfilled the hopes present among the nations of Central and Eastern Europe since the first events leading to the collapse of established social, political and economic system. Poland, just like other post-socialist countries, made many mistakes during the construction of the state mechanisms. New political and social divisions emerged. The voices rejecting the achievements of the Third Republic of Poland in constructing the democratic state, civil society, socially balanced market economy, inter- 
national position of Poland and conditions of accession to European Union can be regularly heard, usually during the electoral campaigns. Fierce campaigns and political struggle are the characteristic of every democracy but in the so called young democracies they lead to inhibitions and distortions of the process of historical political reconstruction. In Poland the approaching presidential and local government election campaigns already involve events complicating the free, conscious decisions of millions of citizens. This is, however, the problem of cultural level and ethical qualifications of the "political class" and her understanding of her role in society and aims, functions and tasks of the state. 